\title{
Analysis of Sudangrass collection cultivars in the Cis-Ural steppe of the Bashkortostan Republic
}

\author{
R.A. Biktimirov*, A.A. Nizaieva, A.Kh. Shakirzyanov, and Z.M. Sharipkulova \\ Bashkir Agricultural Research Institute Bashkir Agricultural Research Institute - a separate structural \\ division of the Ufa Federal Research Center of the Russian Science Academy, Ufa, Russia
}

\begin{abstract}
This paper reports on a study of 62 collection cultivars of Sudangrass evaluated by economic traits for 4 years to create new source material for the Sudangrass selection of higher nutritional value adapted to the Cis-Ural steppe. The research revealed some highly productive and early-maturing Sudangrass cultivars for selecting new varieties highly adaptive to local agro-climatic conditions. Early ripening varieties Chishminskaia ranniaia, Yaktash, Demskaia, Smena, Novosibirskaia 84, Lira had 81-85 days of the interphase period from full sprouts to complete seed ripeness. Highly productive Anastasia, Aiusha, Zernogradskaia 576, and Alexandrina varieties had a fresh yield of more than $41.9 \mathrm{t} / \mathrm{ha}$. Demskaia, Anastasia, Alexandrina, Aiusha had good nutritional qualities of fresh yield (with $10.04-10.51 \%$ protein and $7.80-10.01 \%$ sugar in dry matter): In 2017, the State Variety Testing of a new Sudangrass cultivar Demskaia started. The middle-early Sudangrass variety Demskaia has an average yield of $47.1 \mathrm{t} / \mathrm{ha}$ of green mass, $8.14 \mathrm{t} / \mathrm{ha}$ of absolutely dry matter, and $2.59 \mathrm{t} / \mathrm{ha}$ of seeds.
\end{abstract}

\section{Introduction}

Sudangrass is a highly productive forage crop characterized by nutritional value and multipurpose use. It can provide consistently high yields of fodder mass in conditions of moisture deficiency. This fact makes Sudangrass indispensable for feeding cattle in the summer and preparing different fodders for maintaining livestock in the winter $[2,4,6]$.

However, the insufficient number of early-ripening and high-yielding varieties of Sudangrass with high nutritional qualities is one of the few factors that hinder its wider distribution. This issue can be addressed by breeding programs for this crop $[1,2,8,10]$.

The selection of Sudangrass in the Bashkir Agricultural Research Institute of the Russian Science Academy started in the mid-seventies of the last century. The earlymaturing and high-yielding Chishminskaia ranniaia variety introduced into production in 1997, the improved quality of Sudangrass seed production, and the developed and applied intensive cultivation technology for the conditions of the region under the study contributed to the wider use of Sudangrass in Bashkortostan $[5,10]$.

* Corresponding author: biktimirov.rifx@yandex.ru 
Sudangrass is a relatively new crop in the republic that has spread to more northern areas of the Ural region. It has created new problems in the selection work associated with insufficient ripening of seeds in new conditions. The lack of varieties that mature steadily for seeds and highly productive in terms of feed productivity prevent its further spread in the farms of the Ural region. Thus, developing new early-ripening and cold-resistant varieties is an important direction in selecting this forage crop $[7,8,9]$.

\section{Materials and methods}

The research was conducted in the plant breeding centre of the Bashkir Agricultural Institute of the Russian Science Academy of Sciences in conditions of the Cis-Ural steppe zone of the Bashkortostan Republic in 2017-2020.

Study materials were 62 collection cultivars of Sudangrass developed by the AllRussian Research Institute of Plant Growing named after Nikolai Ivanovich Vavilov and other Russian research institutions engaged in selecting sorghum crops. Another source for the study was the selection material of the Forage Crop Breeding and Seed Production Laboratory of the Bashkir Agricultural Research Institute of the Ural Federal Research Center of the Russian Science Academy. The standard for the research was the Sudangrass variety Chishminskaia ranniaia, adapted to the Ural region.

Field experiments were based on the methodology of the State Crop Variety Testing [12]. The predecessor in the experiment was spring wheat. Seeding by research years was carried out in the period from May 26 to May 29 (depending on weather conditions). The seeding rate of the studied cultivars is 2.0 million germinating seeds per 1 ha. The sowing was carried out with a selection seeder SKS-6-10 with a row spacing of $15 \mathrm{~cm}$. The plot area is $16.2 \mathrm{~m}^{2}$; the accounting area for green mass is $8 \mathrm{~m}^{2}$, for seeds $-5 \mathrm{~m}^{2}$. The variety samples in the experiment were placed systematically in four-fold repetition. All records and related observations were made in accordance with the methodology of the All-Russian Fodder Research Institute named after V.R. Williams [3] and the field experience method [11].

The ripeness groups were determined conditionally by the duration of the interphase period "full sprouts - full ripeness of seeds", taking into account the climate conditions of the region. The feed and nutritional value of the Sudangrass cultivar green mass was examined in the analytical laboratory according to generally accepted methods.

The Cis-Ural steppe zone of the Bashkortostan Republic is moderately warm with a semi-arid and arid climate.

The climate in different parts of the Bashkortostan Republic differs in solar radiation received during the year due to its north-south extent (that results in the latitudinal thermal zonality). The temperature regime in the Republic is characterized by the sharp contrast of the average air temperature in winter and summer. The average annual precipitation is 469 $\mathrm{mm}$, and $266 \mathrm{~mm}$ during the growing season. The hydrothermal index is on average 0.91.0. The frost-free period lasts 120-130 days. The growing season continues about 137 days with an average daily air temperature of more than $10^{\circ} \mathrm{C}$. The sum of active temperatures over $10^{\circ} \mathrm{C}$ is $2230^{\circ} \mathrm{C}$. It is warm enough to cultivate Sudangrass varieties with a growing season of 85-100 days. During this period, Sudangrass develops up to two yields of green mass and a high yield of seeds that differ in the necessary conditions.

The weather conditions and the hydrothermal regime in the growing season during the research years were unstable. The prevailing climatic conditions provided an objective assessment of the studied cultivars.

The obtained data were statistically processed by the method of variance analysis using the "Microsoft Excel" program. 


\section{Results and Discussion}

The study and evaluation of collection cultivars of Sudangrass aimed to identify the sources of early maturity, productivity, quality of fodder mass, and other valuable features and properties are essential in this crop selection [4]. Sudangrass, as a cross-pollinating crop, has a high polymorphism in many morphobiological traits. It provides a more productive selection from the source material.

The study of the collection cultivars of Sudangrass, different in ecological and geographical origin, identified 17 varieties with a complex of economically valuable characteristics and properties. Most Sudangrass cultivars are inferior to the standard variety of the local selection Chishminskaia Ranniaia in terms of ripening.

Among the studied varieties, the most short-season samples were allocated to the earlymaturing group. The period from full sprouts to full ripeness in varieties of this group lasted from 81 to 85 days. The crop height, when harvested for seeds, was from 215 to $230 \mathrm{~cm}$. The most distinctive was Demskaia of $231 \mathrm{~cm}$ and Novosibirskaia 8 of $230 \mathrm{~cm}$. Whereas the standard variety Chishminskaia Ranniaia was $215 \mathrm{~cm}$ (Table 1).

Table 1. Characteristics of economically valuable traits of the Sudangrass collection, 2017-2020.

\begin{tabular}{|c|c|c|c|c|}
\hline Variety & $\begin{array}{l}\text { The period "full } \\
\text { sprouts - full } \\
\text { ripeness", days }\end{array}$ & The crop height, $\mathrm{cm}$ & $\begin{array}{l}\text { The number of } \\
\text { leaves,pcs. }\end{array}$ & $\begin{array}{c}\text { The green mass } \\
\text { yield, } t / \mathrm{ha}\end{array}$ \\
\hline \multicolumn{5}{|c|}{ early-ripening variieties } \\
\hline Chisminskaia ranniaia & 81.2 & 215 & 6 & 29.5 \\
\hline Demskaia & 84.5 & 231 & 7 & 31.1 \\
\hline Iaktash & 83.5 & 223 & 7 & 30.1 \\
\hline Smena & 84.2 & 227 & 7 & 29.9 \\
\hline Novosibirskaia 84 & 83.4 & 230 & 7 & 27.8 \\
\hline Lira & 84.9 & 226 & 7 & 27.6 \\
\hline \multicolumn{5}{|c|}{ mid-ripening cultivars } \\
\hline Priobskaia 97 & 86.9 & 212 & 7 & 30.1 \\
\hline Turan 2 & 86.4 & 201 & 8 & 28.9 \\
\hline Iubileinaia 20 & 89.1 & 208 & 8 & 29.3 \\
\hline Saratovskaia 1183 & 88.7 & 195 & 8 & 29.1 \\
\hline Penzenskaia ranniaia & 87.2 & 190 & 7 & 29.3 \\
\hline Luninskaia & 87.9 & 199 & 7 & 28.9 \\
\hline \multicolumn{5}{|c|}{ middle-late varieties } \\
\hline Zonalskaia 6 & 94.2 & 239 & 9 & 31.0 \\
\hline Zernogradskaia 576 & 104.7 & 274 & 10 & 42.7 \\
\hline Anastasia & 106.7 & 285 & 11 & 54.2 \\
\hline Alexandrina & 109.2 & 299 & 12 & 41.9 \\
\hline Aiusha & 107.0 & 281 & 12 & 46.2 \\
\hline
\end{tabular}

The early-maturing and mid-maturing Sudangrass varieties had insignificant differences in the yield of green mass, plant height, and the number of leaves. The Sudangrass cultivars Demskaia and Smena had the highest yields of green mass. These varieties are short-season and highly productive in green mass, being 31.1 and $30.1 \mathrm{t} / \mathrm{ha}$ against $29.5 \mathrm{t} / \mathrm{ha}$ of the standard variety Chishminskaia ranniaia.

The growing season of the middle-maturing varieties was 86-89 days, 4-5 days longer than the early-maturing cultivars. Priobskaia 97 and Iubileinaia 20 were prominent by height, 212 and $208 \mathrm{~cm}$ against $215 \mathrm{~cm}$ of the standard. 
Among the mid-season varieties, the following cultivars had the highest yields of green mass: Priobskaia 97 (30.1 t/ha), Iubileinaia 20 and Penzinskaia ranniaia (29.3 t/ha respectively) against $29.5 \mathrm{t} / \mathrm{ha}$ of the standard.

The interphase period "full sprouts - full ripeness of seeds" of the middle-late varieties ranged from 94 to 109 days. They ripen later than the standard by more than 3 weeks. The middle-late cultivars were high $(239-299 \mathrm{~cm})$. According to this characteristic, the most prominent was Alexandrina $(299 \mathrm{~cm})$ and Anastasia $(285 \mathrm{~cm})$.

The Anastasia variety among the studied middle-late cultivars was distinguished by the yield of green mass being $54.2 \mathrm{t} / \mathrm{ha}$. Most varieties of this group significantly exceed the standard Chishminskaia ranniaia by $42-84 \%$.

The number of leaves and their area significantly impact the quality indicators of the fodder from Sudangrass. The middle-late Sudangrass cultivars Anastasia, Alexandrina, Aiusha, Zernogradskaia 576 had longer and wider leaves. The early-maturing and midmaturing varieties were characterized by an average leaf coverage of 6-8 leaves per stem. The middle-late cultivars had a dense leafiness of 9-12 leaves per stem.

The Sudangrass fodder quality is largely determined by its nutritional value. The harvested green mass of the first mowing, carried out in the phase of "the paniculation beginning", was analyzed for nutritional value. The biochemical analysis made it possible to determine the content of crude protein, sugars, fat, fibre, and nitrogen-free extractives in the dry matter (Table 2). The conducted research distinguished the Sudangrass varieties with the highest content of crude protein: Demskaia - 10.51\%, Anastasia- $10.49 \%$, Alexandrina-10.22 \% and Aiusha-10.04\%. This indicator for the standard variety Chishminskaia Ranniaia was equal to $9.42 \%$. The highest sugar content was found in the middle-late varieties Alexandrina $-10.01 \%$ and Aiusha $-9.25 \%$ against $6.12 \%$ of the standard Chishminskaia ranniaia. In the early- and mid-maturing cultivars, this indicator was significantly lower and varied from 6.12 to $8.02 \%$. The fibre content in the green mass of the Sudangrass cultivars was the highest in the short-season varieties being $31-34 \%$, the lowest in the mid-late group being $30-32 \%$.

Table 2. Chemical composition of Sudangrass plants, \% per absolutely dry substance.

\begin{tabular}{|c|c|c|c|c|}
\hline Variety & Protein & Sugar & Fibre & $\begin{array}{l}\text { Nitrogen-free } \\
\text { extractives }\end{array}$ \\
\hline \multicolumn{5}{|c|}{ early-ripening variieties } \\
\hline Chisminskaia ranniaia & 9,42 & 6.12 & 34.21 & 48.23 \\
\hline Demskaia & 10.51 & 7.80 & 31.08 & 48.51 \\
\hline Iaktash & 9.20 & 7.96 & 31.25 & 49.44 \\
\hline Smena & 9.12 & 8.02 & 32.15 & 48.49 \\
\hline Novosibirskaia 84 & 8.42 & 7.05 & 33.12 & 49.21 \\
\hline Lira & 9.14 & 7.01 & 33.05 & 48.68 \\
\hline \multicolumn{5}{|c|}{ mid-ripening cultivars } \\
\hline Priobskaia 97 & 9.79 & 8.02 & 31.65 & 48.12 \\
\hline Turan 2 & 9.10 & 7.81 & 32.95 & 48.13 \\
\hline Iubileinaia 20 & 8.76 & 7.92 & 32.89 & 48.29 \\
\hline Saratovskaia 1183 & 9.51 & 7.94 & 31.95 & 48.41 \\
\hline Penzenskaia ranniaia & 9.38 & 6.98 & 32.64 & 48.89 \\
\hline Luninskaia & 9.52 & 7.40 & 32.99 & 47.51 \\
\hline \multicolumn{5}{|c|}{ middle-late varieties } \\
\hline
\end{tabular}




\begin{tabular}{|l|c|c|c|c|}
\hline Zonalskaia 6 & 9.98 & 7.96 & 32.21 & 47.72 \\
\hline Zernogradskaia 576 & 9.85 & 8.15 & 31.65 & 48.41 \\
\hline Anastasia & 10.49 & 9.12 & 30.24 & 48.14 \\
\hline Alexandrina & 10.22 & 10.01 & 30.14 & 47.61 \\
\hline Aiusha & 10.04 & 9.25 & 30.51 & 48.12 \\
\hline
\end{tabular}

There were no significant differences in the content of nitrogen-free extractives in cultivars of different ripeness. This indicator ranged from 47.51 to $49.44 \%$

An important economic feature in assessing the results of breeding is seed productivity. The seed yield of the collection samples of Sudangrass, depending on the ripeness groups, was $0.42-2.79 \mathrm{t} / \mathrm{ha}$ (Fig.1).

The highest seed productivity was provided by early-maturing cultivars Demskaia (2.79 $\mathrm{t} / \mathrm{ha})$, Smena (2.61 t/ha), Iaktash (2.49 t/ha). In comparison, the standard variety Chishminskaia ranniaia had a seed yield of $2.44 \mathrm{t} / \mathrm{ha}$. In general, the seed yield of earlymaturing cultivars varied within 2.08-2.79 t/ha. Among the mid-season varieties with seed productivity 1.31-2.11 t/ha, Priobskaia $97(2.11 \mathrm{t} / \mathrm{ha})$ and Turan $2(1.97 \mathrm{t} / \mathrm{ha}) \mathrm{had}$ the highest. Middle-late varieties of Sudangrass had the lowest seed yield (0.42-1.32 t / ha) since they could not fully use the climatic resources for their growth and development in the conditions of the research site.

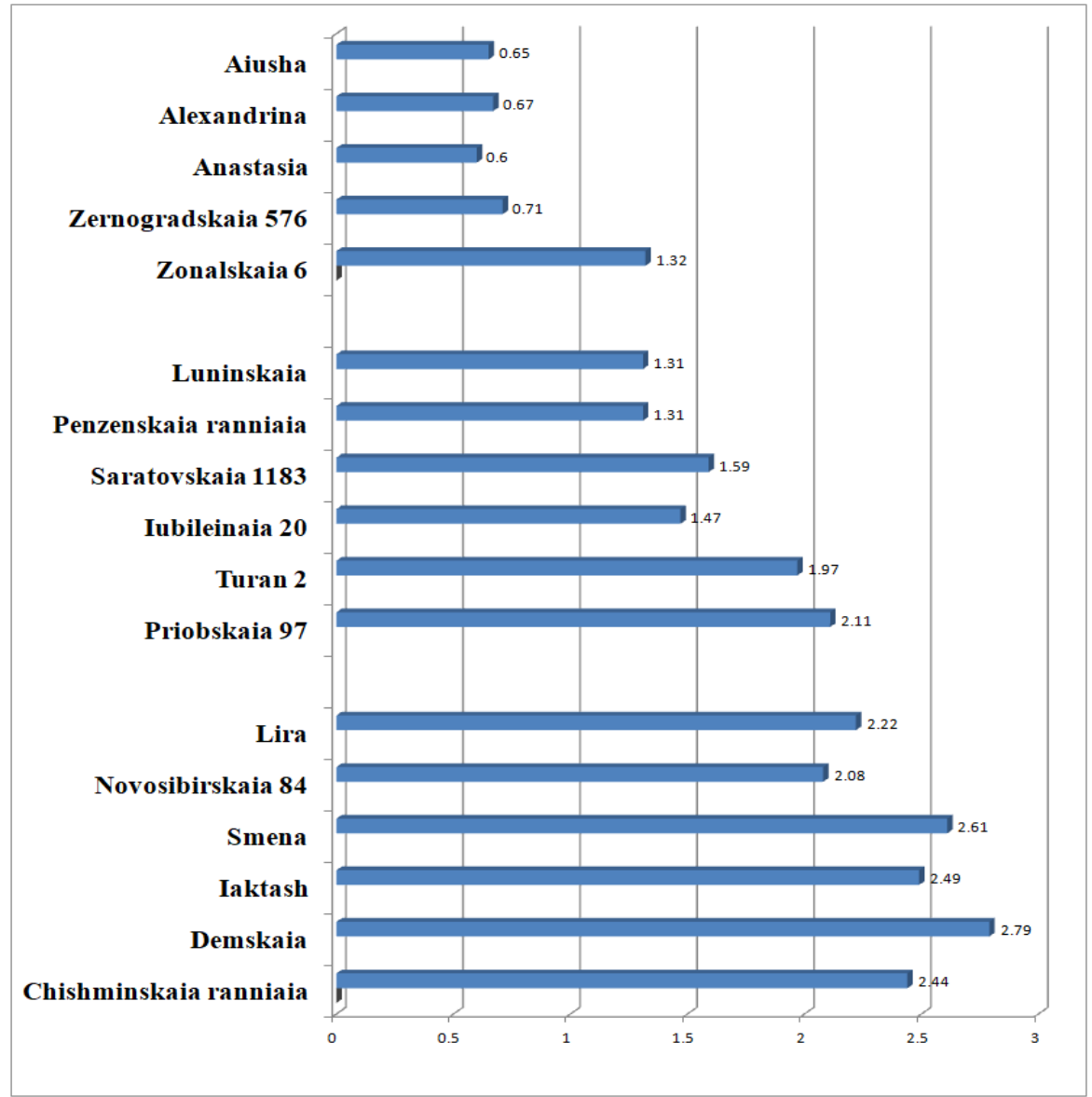

Fig. 1. Seed yields of different ripeness Sudangrass varieties, $\mathrm{t} / \mathrm{ha}$. 
The most distinctive among the early-maturing group was the Sudangrass variety Demskaia. According to the results of the competitive testing for 2014-2017, it was sent to the State Variety Testing. Since 2017 it has been tested at the variety test plots of the Central, Volga-Viatka, Middle Volga and Ural regions of Russia. The Demskaia cultivar was obtained by a repeated individual and family-group selection of the most productive plants from a hybrid population characterized by intensive initial growth resulting from the hybridization of the sugar sorghum variety Kinelskoe 3 Sudangrass cultivar Chishminskaia ranniaia.

The variety is medium-early, with a period from full sprouts to the first mowing of 33 41 days and from full sprouts to full seed ripeness of 78 days. The variety is characterized by an intensive rate of development in the initial period $-79.4 \mathrm{~cm}$ in the first 30 days of the growing season (from germination to complete paniculation). It grows well after mowing (Fig. 2).

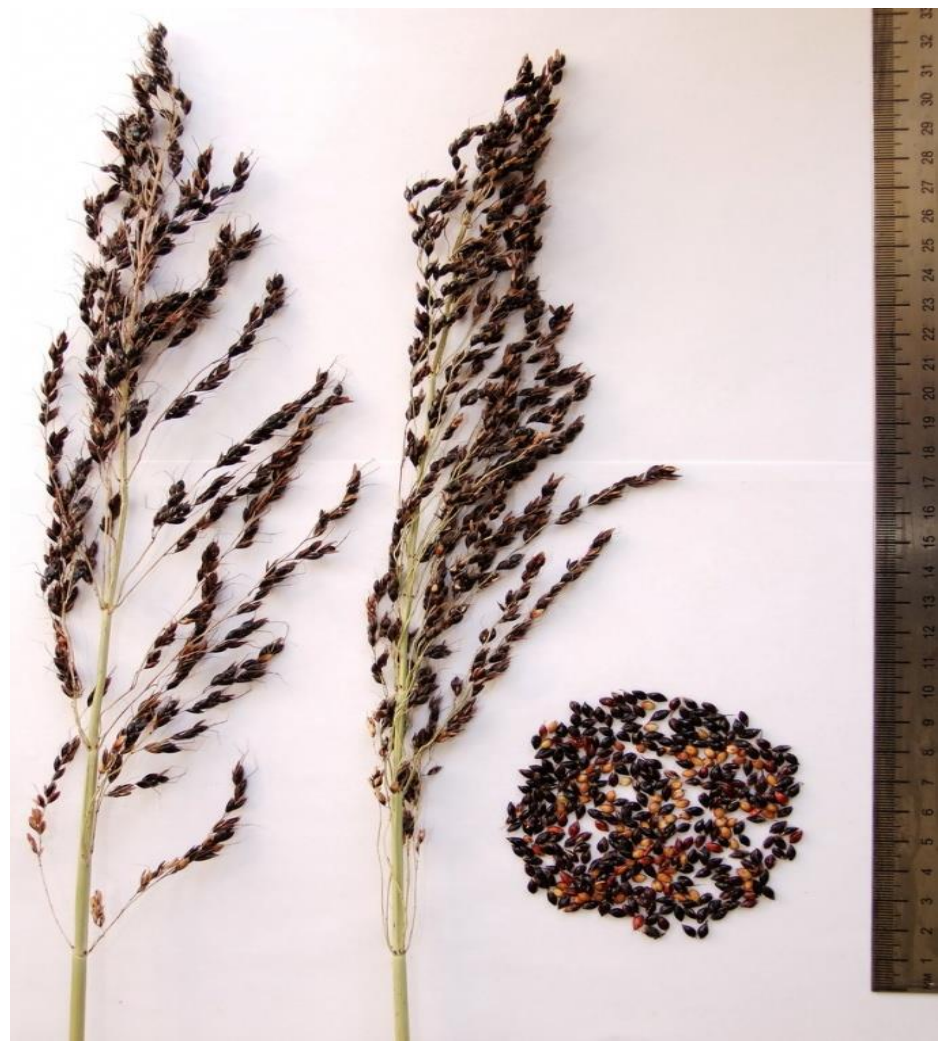

Fig. 2. Panicles and seeds of a new Sudangrasss variety Demskaia.

The yield of the Demskaia variety, according to the average long-term data in the competitive variety testing was: green mass $-47.1 \mathrm{t} / \mathrm{g}$, absolutely dry matter- $8.14 \mathrm{t} / \mathrm{ha}$ and seeds-2.59 t / ha, which exceeds the standard Chishminskaia Ranniaia by $17-28 \%$. It exceeds the standard in terms of sugar content in the green mass $(7.8 \%)$ by $3.8 \%$, in terms of protein content $(10.5 \%$ ) by $1.5 \%$ (Table 3$)$.

The height of the plants is $217 \mathrm{~cm}$, they are of average tilling capacity, thin-stemmed, the number of leaves is 6-7. The leaf is broadly linear, lanceolate, up to $47 \mathrm{~cm}$ long, up to $2.8 \mathrm{~cm}$ wide. It is resistant to red bacterial spotting. The colour of the spikelet scales is black, $10-15 \%$ of a cherry-red colour. The fruiting spikelets are diamond-shaped, the awns 
are cranially curved. The grain is elliptical, light brown and straw-yellow. Weight of 1000 seeds is $15.0 \mathrm{~g}$.

Table 3. Yield data of the promising Sudangrass variety Demskaia in comparison with the standard variety Chishminskaia Ranniaia (on average for 2014-2017)

\begin{tabular}{|l|c|c|c|c|}
\hline & \multirow{2}{*}{ Indicators } & \multirow{2}{*}{$\begin{array}{c}\text { Standard } \\
\text { Chishminskaia } \\
\text { ranniaia }\end{array}$} & t/ha & $\%$ \\
\cline { 4 - 5 } & & 39,8 & $+7,3$ & +18 \\
\hline Green mass yield, t/ha & 47,1 & 6,93 & $+1,21$ & +17 \\
\hline Dry matter & 8,14 & 2,02 & $+0,57$ & +28 \\
\hline Seed yield & 2,59 & 44 & & +5 \\
\hline Leafiness rate, \% & 49 & 9,0 & & $+1,5$ \\
\hline $\begin{array}{l}\text { Protein content in dry } \\
\text { matter, \% }\end{array}$ & 10,5 & 4,0 & & $+3,8$ \\
\hline sugar content, \% & 7,8 & 76 & +2 & \\
\hline $\begin{array}{l}\text { The period fro full } \\
\text { sprouts to full seed } \\
\text { ripeness, days }\end{array}$ & 78 & & & \\
\hline
\end{tabular}

\section{Conclusions}

As a result of studying the Sudangrass collection material, a rich gene pool for high productivity, early maturity and feed quality has been identified, which should be used in the selection of new varieties that are highly adaptive to local agro-climatic conditions. There have been distinguished short-season cultivars as Chishminskaia ranniaia, Iaktash, Demskaia, Smena, Novosibirskaia 84, Lira with 81-85 days of the growing season. Anastasia, Aiusha, Zernogradskaia 576, and Alexandrina were found to be highly productive with a yield of greem mass more than 41.9 t/ha. Demskaia, Anastasia, Alexandrina, Aiusha had good nutritional qualities of fresh yield (with $10.04-10.51 \%$ protein and $7.80-10.01 \%$ sugar in dry matter):

In 2017, a new middle-early Sudangrass variety Demskaia was given to the State variety Testing. The cultivar has a high yield of green mass $(7.1 \mathrm{t} / \mathrm{ha})$, absolutely dry matter $(8.14$ t/ha) and seeds (2.59 t/ha).

\section{References}

1. S.V. Kadyrov, Sorghum in the Central Chernozem regions, 80 (Rostov-on-don, 2008

2. N.I. Kashevarov, R.I. Polyudina, N.V. Balykina, A.P. Shtaus, Sudan grass in forage production in Siberia, 224 (Novosibirsk, 2004)

3. Yu.K. Novoselov, G.D. Kharkiv, N.S. Shekhovtsova, Methodological guidelines for conducting field experiments with forage crops, 198 (operational printing Division of the VIC, Moscow, 1983)

4. N.A. Kovtunova, E.A. Shishova, A.E. Romanyukin, V.V. Kovtunov, N.N. Sukhenko, Grain Economy of Russia, 1, 56-61(2018)

5. R.A. Biktimirov, A.Kh. Shakirzyanov, A.A. Nizaeva, Achievements of Science and Technology of AIC, 8(33), 46-49 (2019)

6. N.A. Kovtunova, Achievements of Science and Technology of AIC, 6(30), 48-51 (2016) 
7. S.S. Kukoleva, D.S. Semin, O.P. Kibalnik, V.I. Starchak, Grain Economy of Russia, 4, 8-11 (2016)

8. G.M. Ermolina, N.A. Kovtunova, A.E. Romanyukin, E.A. Shishova, Agrarian Bulletin of the Urals, 04(158), 16-20 (2017)

9. Y.R. Shukis, S.K. Shukis, Bulletin of the Altai State Agrarian University, 8(154), 2327(2017)

10. R.A. Biktimirov, Z.M. Sharipkulova, A.A. Nizaeva, Agrarian Bulletin of the Urals, 10(201), 2-7 (2020)

11. B.A. Dospekhov, Methodology of a field trial (with the basis of statistic processing of study results), 351 (Alyans, Moscow, 2014)

12. State methodology for crop variety testing 250 (Moscow, 1989) 